\title{
UPAYA MANAGER PADA CREDIT UNION DALAM MENANGGULANGI KREDIT MACET
}

\author{
Evy Ratnasari \\ Fakultas Ilmu Sosial dan Ilmu Politik Universitas Kapuas
}

\begin{abstract}
Abstrak : Prosedur penyaluran kredit pada CU Bina Masyarakat Sintang dilakukan dengan penelitian syarat administrasi, yang menyangkut persyaratan-persyaratan yang harus dipenuhi oleh seseorang untuk dapat memperoleh fasilitas kredit atau pinjaman, setelah syarat-syarat administrasi dipenuhi maka akan dilakukan analisa kredit oleh bagian kredit yang menyangkut beberapa aspek, dan seberapa besar anggota dapat diberikan pinjaman sesuai dengan kemampuannya. Kemudian mengenai teknik yang digunakan dalam menyelesaikan masalah kredit macet adalah dengan melakukan pengendalian kredit selanjutnya jika sudah terjadi akan dilakukan langkah-langkah administrasi untuk penyelesaian kredit macet tersebut. Faktor-faktor yang mempengaruhi terjadinya kredit macet adalah faktor intern yang berasal dari dalam CU ini sendiri, dan faktor ekstern yang berasal dari nasabah atau debitur.
\end{abstract}

Kata Kunci : Menanggulangi, Kredit Macet.

Sejak dilahirkan manusia telah menghadapi masalah untuk bisa tetap hidup dan berusaha mempertahankan kelangsungan hidupnya dengan bekerja untuk dapat memenuhi kebutuhannya. Salah satu permasalahan yang dihadapi manusia adalah masalah ekonomi, sebagai mahluk sosial manusia manusia tidak bisa hidup sendiri karena harus salin mendukung dan saling membutuhkan antara satu sama lainnya dalam upaya mempertahankan hidup. Sifat saling memerlukan dan saling mendukung inilah yang membuat manusia sebagai mahluk sosial harus bekerjasama. Dalam mengatasi kesulitankesulitan dan tuntutan zaman yang semakin meningkat, maka timbul suatu ide untuk mendirikan suatu perkumpulan dan menggalang kerjasama yang bertujuan untuk mensejahterakan para anggota.pemikiran inilah yang merupakan cikal bakal terbentuknya sebuah lembaga yang dinamakan koperasi. Koperasi sebagai badan usaha yang bertujuan memajukan dan meningkatkjan kesejahteraan para anggotanya dan juga untuk memenuhi kebutuhan masyarakat serta ikut membangun tatanan perekonomian nasional dalam rangka mewujudkan masyarakat yang maju, adil dan makmur. Untuk itu koperasi harus terus meningkatkan kegiatan usahanya untuk mencapai tujuan yang diinginkan demi tercapainya kesejahteraan anggota khususnyta dan masyarakat luas umumnya.

Setiap perusahaan mempunyai tujuan untuk dapat tetap hidup dan berkembang. Tujuan tersebut hanya dapat tercapai apabila melalui usaha mempertahankan dan meningkatkan keuntungan tingkat keuntungan atau laba perusahaan. Koperasi kredit sebagai salah satu usaha koperasi yang bergerak dalam bidang simpan pinjam tentu sangat tergantung dari penyaluran kredit yang dikeluarkan koperasi, karena dari bunga pinjaman yang diberikan koperasi memperoleh keuntungan. Selisih antara bunga pinjaman dengan bunga simpanan adalah merupakan keuntungan bagi koperasi kredit. Menurut Musselman dan Jackson (dalam Wiriadisastra, 1992:102) "kredit adalah kemampuan untuk mendapatkan barang atau jasa dengan pertukaran suatu janji untuk membayar kemudian". Pendapat tersebut menunjukkan bahwa kredit mengandung unsur kepercayaan, yaitu pihak kreditur percaya kepada keinginan dan kemampuan dari debitur untuk memenuhi janji akan membayar, oleh karena itu kreditur bersedia memberikan barang, jasa dan uang. Sedangkan dari pihak debitur berarti menerima kepercayaan, yaitu berkewajiban untuk membayar pinjamannya sesuai dengan jangka waktu yang telah ditentukan. Kredit berasal dari Bahasa Yunani credere/creditum yang artinya percaya atau kepercayaan. Menurut Elias dan Situngkir (2006:17): Kredit adalah kemampuan untuk melaksanakan sesuatu pembelian atau pengadaan suatu pinjaman dengan jani pembayarannya akan dilakukan/ditangguhkan pada suatu jangka yang disepakati. Kredit adalah penyediaan uang atau tagihan yang dapat disamakan dengan ini berdasarkan persetujuan pinjam meminjam antara kopdit dengan anggota/pihak lain, dalam hal mana anggota/pihak peminjam berkewajiban melunasi hutangnya setelah jangka waktu tertentu dengan jumlah bunga yang telah ditentukan. Menurut Wojowasito dan Warsito (2002:35) "kredit di dalam Bahasa Inggris yaitu credit memiliki arti yaitu percaya. Artinya dengan mendapat kredit berarti mendapat kepercayaan". Selanjutnya menurut Winardi (2001:84) "kredit adalah sebuah perjanjian pembayaran dikemudian 
hari berupa uang, barang-barang atau jasa yang diterima pada masa sekarang". Dapat dikatakan bahwa kredit berkaitan dengan dua hal yaitu masa pada saat diberikan (masa sekarang) dan masa pada saat mengembalikan (masa yang akan datang). Dalam Koperasi Kredit, kredit yang diberikan kepada anggotanya adalah berupa uang yang digunakan untuk pengembangan usaha maupun kebutuhan lain yang bersifat positif.

Undang-Undang Perbankan Nomor 10 Tahun 1998 menjelaskan kredit adalah: "Penyediaan uang atau tagihan yang dapat dipersamakan dengan itu, berdasarkan persetujuan atau kesepakatan pinjam meminjam antara bank dengan pihak lain yang mewajibkan pihak peminjam melunasi utangnya setelah jangka waktu tertentu dengan jumlah bunga, imbalan atau pembagian hasil keuntungan". Dalam pemberian kredit terdapat dua pihak yang berkepentingan langsung dengan pihak yang memiliki uang, yang disebut pihak pemberi kredit, dan pihak yang memerlukan uang disebut pihak penerima kredit, artinya jika terjadi pemberian kredit maka pihak yang memiliki uang memberikan uangnya kepada pihak yang memerlukan uang dan akibatnya pihak penerima uang berkewajiban mengembalikan uang yang diberikan pada masa yang akan datang, hubungan timbal balik inilah yang dapat menimbulkan suatu akibat/resiko kelalaian terhadap pengembalian kredit yang diberikan, oleh karena itu untuk menghindari hal tersebut diperlukan adanya langkah-langkah antisipatif agar dapat dihindari kredit macet. Kredit harus dikelola dengan prinsip kehati-hatian akan menempatkan pada kualitas kredit yang bermutu sehingga dapat memberikan pendapatan yang besar bagi koperasi kredit. Pendapatan yang diperoleh dari kegiatan perkreditan berupa selisih antara biaya dengan pendapatan bunga yang dibayarkan para peminjam. Dengan demikian keberhasilan bagian kredit dalam usaha menjaga kualitas kredit berupa pembayaran bunga dan angsuran pokok yang lancar merupakan sumbangan yang besar bagi suksesnya usaha koperasi kredit. Oleh karena itu maka hendaknya perlu adanya analisis kredit yang akurat dan mendalam oleh petugas kredit guna mengurangi resiko kredit bermasalah atau macet.

Kredit yang diberikan oleh suatu lembaga kredit didasarkan atas kepercayaan, sehingga dengan demikian pemberian kredit merupakan pemberian kepercayaan. Ini berarti bahwa suatu lembaga kredit baru akan memberikan kredit kalau betul-betul yakin bahwa si penerima kredit akan mengembalikan kredit yang diterimanya sesuai dengan jangka waktu dan syarat-syarat yang telah disetujui oleh kedua belah pihak. Tanpa adanya keyakinan tersebut, suatu lembaga kredit dipastikan tidak akan meneruskan sampai kepada pemberian kredit. Menurut Suyatno (2003:14) ada 4 (empat) unsur yang terdapat dalam hal perkreditan, yaitu: Kepercayaan, yaitu keyakinan dari si pemberi kredit bahwa prestasi yang diberikannya baik dalam bentuk uang, barang atau jasa, akan benar-benar diterimanya kembali dalam jangka waktu tertentu di masa yang akan datang. Waktu, yaitu suatu masa yang memisahkan antara pemberian prestasi dengan kontraprestasi yang akan diterima pada masa yang akan datang. Dalam unsur waktu ini, terkandung pengertian nilai agio dari uang yaitu uang yang ada sekarang lebih tinggi nilainya dari uang yang akan diterima pada masa yang akan datang. Degree of risk, yaitu suatu tingkat resiko yang akan dihadapi sebagai suatu akibat dari adanya jangka waktu yang memisahkan antara pemberian prestasi dengan kontraprestasi yang akan diterima kemudian hari. Semakin lama kredit diberikan, semakin tinggi pula tingkat resikonya, karena sejauh kemampuan manusia untuk menerobos haru depan itu, maka masih selalu terdapat unsur ketidaktentuan yang tidak dapat diperhitungkan, inilah yang menyebabkan unsur resiko. Dengan adanya unsur resiko inilah maka timbullah jaminan dalam pemberian kredit. Prestasi atau objek kredit itu tidak hanya diberikan dalam bentuk uang, tetapi juga dapat berbentuk barang atau jasa.

\section{Syarat Administrasi.}

Kredit yang dimaksud dalam koperasi kredit adalah pinjaman anggota koperasi yang didasarkan pada besarnya Simpanan Saham serta Simpanan Sukarela Anggota (SSA), dan melalui tahap-tahap tertentu, untuk keperluan dirinya sendiri atau keluarga yang menjadi tanggungannya. Keputusan Pengurus Kopdit Bima Nomor 001 Tahun 2008 tentang Pola Kebijakan Pengurus Kopdit Bima, (2008:5) ketentuan umum pinjaman adalah sebagai berikut :

a) Yang boleh meminjam adalah anggota biasa yang sudah mengikuti Pendidikan Dasar, dan aktif menabung lebih dari 2 (dua) bulan.

b) Jatuh tempo angsuran setiap bulan sesuai dengan tanggal pencairan pinjaman atau paling lambat pada setiap akhir bulan.

c) Apabila lewat dari batas waktu kewajiban mengangsur sebagaimana point (b) atau menunggak, dikenakan denda sebesar 3\% dari jumalh tunggakan angsuran pokok dan atau bunga.

d) Sebagai kompensasi atas dialokasikannya bunga setiap bulan untuk SSA, maka bagi anggota yang menunggak akan dilakukan pemotongan dari SSA sebesar tunggakan (angsuran pokok, bunga dan denda) pada bulan berikutnya. Pemotongan akan dilakukan mulai pada tanggal 6 setiap bulan.

e) Khusus bagi anggota yang menyetor lewat Petugas Lapangan atau Korwil, toleransi pembayaran tidak lewat dari tanggal 
kunjungan Khusus bagi anggota yang menyetor lewat Petugas Lapangan atau Korwil, toleransi pembayaran tidak lewat dari tanggal kunjungan

f) Pinjaman yang hampir jatuh tempo, sedangkan peminjam tidak mampu melunasinya sesuai batas waktu perjanjian karena kemampuan bayar menurun (bukan karena lalai/sengaja), dapat dilakukan jadwal ulang, dengan ketentuan tetap melalui permohonan, diputuskan, dan dicairkan, dengan biaya administrasi sebagaimana pinjaman baru.

g) Boleh mengajukan pinjaman berikutnya apabila pinjaman sebelumnya sudah diangsur paling kurang $50 \%$.

h) Besar angsuran pokok pinjaman paling kurang Rp.50.000,- setiap bulan.

Dari ketentuan umum di atas, diketahui bahwa yang boleh meminjam adalah anggota biasa yang sudah mengikuti pendidikan dasar dan aktif menyimpan atau menabung pada Kopdit serta sudah menjadi nasabah tabungan minimal 2 bulan.

\section{Analisa Kredit.}

Koperasi kredit dalam memberikan pinjaman atau fasilitas kredit kepada anggota terlebih dahulu harus melakukan analisa kredit kepada anggota yang akan diberikan kredit, hal ini dilakukan untuk menilai sejauh mana anggota dapat memperoleh pinjaman dan kemampuan mengembalikannya, guna mengantisipasi sedini mungkin adanya kredit macet. Kasmir (2003:101) mengemukakan bahwa :

Untuk meyakinkan kreditur bahwa si nasabah benar-benar dapat dipercaya, maka sebelum kredit diberikan terlebih dahulu kreditur mengadakan analisis kredit. Analisis kredit mencakup latar belakang nasabah, prospek usahanya, jaminan yang diberikan serta faktor-faktor lainnya. Tujuan analisis ini adalah agar kreditur yakin bahwa kredit yang diberikan benar-benar aman. Pemberian kredit tanpa dianalisis terlebih dahulu akan sangat membahaya usaha koperasi kredit. Nasabah dalam hal ini dengan mudah memberikan data-data fiktif. Kemudian juga salah dalam menganalisis, maka kredit yang disalurkan yang sebenarnya tidak layak menjadi layak, sehingga akan berakibat sulit untuk ditagih atau macet. Syamsuddin (20021:264) mengemukakan bahwa: Ada dua faktor yang harus dilaksanakan oleh perusahaan dalam mengadakan penilaian terhadap calon langganan yang akan diberikan kredit, yaitu : (a) memperoleh informasi tentang keadaan langganan misalnya dengan cara mengisi formulir sehubungan dengan keadaan finansial; (b) menganalisa laporan keuangan dan buku besar utanag untuk menentukan umur rararata utang dagang para calon langganan.
Dalam menganalisa kredit harus selalu memperhatikan prinsip-prinsip perkreditan yang dikenal dengan istilah five Cs of credit $(5 \mathrm{C})$. Menurut Siamad (2006:109) sebagai berikut:

a) Character (watak/kepribadian)

Penilaian terhadap karakter ini perlu dilakukan untuk mengetahui sejauh mana etikat baik dan kejujuran calon nasabah debitur untuk membayar kembali kredit yang telah diterimanya.

b) Capacity (kemampuan)

Penilaian terhadap capacity dari debitur dilakukan untuk mengetahui sejauh mana kemampuan debitur mengembalikan pokok pinjaman serta bunga pinjamannya. Penilaian kemampuan membayar tersebut dilihat dari kegiatan usaha dan kemampuannya melakukan pengelolaan atas usaha yang akan dibiayai melalui kredit.

c) Capital (modal)

Penilaian terhadap capital bertujuan untuk menilai apakah debitur tersebut memiliki modal yang memadai dalam menjalankan usahanya.

d) Collateral (jaminan atau agunan)

Penilaian terhadap barang jaminan yang diserahkan debitur sebagai jaminan atas kredit bank yang diperolehnya. Fungsi jaminan disini adalah sebagai alat pengaman terhadap kemungkinan tidak mampunya debitur melunasi kredit yang diterima.

e) Condition (kondisi perekonomian)

Penilaian terhadap kondisi ekonomi untuk mengetahui mengenai kondisi pada suatu saat di suatu daerah yang mungkin akan mempengaruhi kelancaran usaha debitur, seperti turun naiknya harga, persaingan, kebijakan moneter dan sebagainya.

Teknik yang Digunakan oleh CU. Bima Sintang Dalam Menyelesaikan Masalah Kredit Macet.

\section{Pengendalian Kredit.}

Pengendalian merupakan suatu proses menentukan kesesuaian tindakan dengan rencana yang sudah ditentukan sebelumnya. Pengendalian juga dikuti dengan tindakan pencegahan, oleh karena itu dalam pengendalian kredit hal yang perlu diperhatikan lebih dahulu adalah seleksi terhadap calon peminjam Dengan adanya seleksi tersebut diharapkan dapat memperkecil resiko kelalaian dalam pengembalian kredit. Menurut Hendrojogi (2006:126) "pengendalian adalah suatu aktivitas manajemen yang bertujuan untuk menjaga dan mencegah terjadinya hal-hal yang tidak diinginkan". Jadi tujuan utama dari pengendalian adalah memastikan bahwa hasil kegiatan sesuai dengan apa yang telah direncanakan atau dengan kata lain 
mengusahakan agar usaha selalu berjalan dengan lancar. Pengendalian bersifat korektif artinya bahwa bilamana terjadi penyimpanganpenyimpangan dapat diketahui sedini mungkin, jadi bukan merupakan fungsi negative dari manajemen. Yang dimaksud dengan pengendalian kredit di sini adalah kebijakan yang diambil oleh pengurus koperasi kredit dalam usaha menjaga aktiva lancar yang berwujud tagihan yang timbul karena adanya pemberian pinjaman kepada para anggota dan senantiasa menjaga agar tidak terjadi tunggakan pengembalian kredit, sehingga likuiditas arus kas menyangkut pemberian dan pengembalian kredit dapat berjalan lancar sesuai dengan rencana yang telah disepakati sebelumnya.

\section{Prosedur administrasi dalam penyelesaian kredit macet.}

Setiap kredit yang diberikan memiliki jangka waktu tertentu, jangka waktu ini mencakup masa pengembalian kredit yang telah disepakati. Akibat adanya tenggang waktu, maka pengembalian kredit dimungkinkan suatu resiko tidak tertagihnya atau macet pengembalian kreditnya. Resiko yang ditimbulkan dari pemberian kredit dapat berupa resiko yang disengaja oleh nasabah, maupun resiko yang tidak disengaja, misalnya karena bencana alam atau bangkrutnya usaha nasabah tanpa ada unsur kesengajaan lainnya, sehingga nasabah tidak mampu melunasi kredit yang diperolehnya. Dalam hal kredit macet pihak kopdit perlu melakukan penyelamatan, sehingga dapat meminimalisir jumlah kerugian kopdit. Menurut Syamsudin (2001:273) prosedur yang dapat dilakukan dalam menangani kredit macet, adalah sebagai berikut:

1) Melalui surat, bila mana nasabah belum melakukan pembayaran pada waktu jatuh tempo pembayaran, maka perusahaan dapat mengirim surat dengan nada mengingatkan (menegur), dan apabila utang tersebut belum juga dibayar setelah beberapa hari surat dikirimkan, maka dapat dikirimkan surat kedua yang nadanya lebih keras.

2) Melalui telepon, apabila teguran melalui surat hutang-hutang tersebut belum dibayar, maka secara pribadi perusahaan dapat menelpon nasabah dan memintanya untuk segera melakukan pembayaran. Apabila dari hasil pembicaraan tersebut ternyata misalnya pihak nasabah mempunyai alasan yang dapat diterima, maka mungkin perusahaan dapat memberikan perpanjangan sampai jangka waktu tertentu.

3) Kunjungan personal, melakukan kunjungan secara personal atau pribadi ke tempat nasabah harus seing dilakukan, karena sangat efektif dalam usaha pengumpulan piutang.
4) Tindak yuridis, bila mana nasabah tidak mau membayar hutang-hutangnya, maka perusahaan dapat menggunakan tindakan-tindakan hukum dengan mengajukan gugatan perdata melalui pengadilan.

Dalam usaha pengumpulan piutang suatu perusahaan dapat mengikuti suatu prosedur yang telah ditetapkan bila mana piutang tersebut sudah jatuh tempo. Dalam usaha pengumpulan piutang sebuah kopdit haruslah berhati-hati untuk tidak terlalu agresif dalam usaha-usaha pengumpulan piutang dari nasabah. Bilamana nasabah tidak dapat membayar tepat pada waktunya maka sebaiknya kopdit menunggu sampai jangka waktu tertentu yang dianggap wajar sebelum menerapkan prosedur-prosedur pengumpulan piutang yang ditetapkan Menurut Husnan (1998:481) "terhadap nasabah yang terlambat membayar piutangnya, dilakukan prosedur sebagai berikut: (1) mengirimkan surat teguran yang menjelaskan bahwa nasabah telah terlambat melunasi hutangnya; (2) menelpon atau menghubungi nasabah secara langsung; (3) menggunakan perusahaan jasa pengumpul piutang; (4) menempuh prosedur pengadilan terhadap nasabah".

Dari pendapat tersebut di atas menunjukkan bahwa dalam mengatasi kredit macet suatu perusahaan/ koperasi kredit harus segera melakukan langkahlangkah penyelamatan. Dimana pihak kopdit dapat menggunakan cara melalui pengiriman surat teguran, apabila teguran melalui pengiriman surat hutang tersebut belum dibayar, selanjutnya pihak kopdit dapat menelpon nasabah tersebut, selanjutnya dapat melakukan kunjungan personal kepada nasabah, yang mana cara ini sering kali digunakan karena merupakan cara paling efektif, langkah terakhir yang dapat ditempuh apabila nasabah tidak mau membayar hutang-hutangnya, maka dapat dilakukan tindakan yuridis yaitu dengan menempuh jalur hukum. Kesemuanya itu dilakukan oleh kopdit agar dapat meminimalkan kerugian yang ada sehubungan dengan adanya kredit macet tersebut.

Faktor-faktor yang Menyebabkan Terjadinya Kredit Macet pada CU. Bima Sintang Dalam Memberikan Fasilitas Kredit Kepada Nasabah.

Pemberian suatu fasilitas kredit mengandung suatu resiko kemacetan. Akibatnya kredit tidak dapat ditagih sehingga menimbulkan kerugian yang harus ditanggung oleh kopdit. Sepandai apapun analisis kredit dalam menganalisa setiap permohonan kredit, kemungkinan kredit tersebut macet pasti ada, yang bisa saja dipengaruhi oleh faktor intern dan faktor ekstern. Hanya saja dalam hal ini, bagaimana meminimalkan resiko tersebut seminimal mungkin. Menurut Kasmir 
(2003:128) kemacetan suatu kredit disebabkan oleh dua unsur, yaitu:

1. Dari pihak perusahaan (intern), artinya dalam melakukan analisisnya, pihak analis kurang teliti, sehingga apa yang seharusnya terjadi, tidak diprediksi sebelumnya, atau mungkin salah dalam melakukan perhitungan. Dapat pula terjadi akibat kolusi dari pihak analis kredit dengan pihak debitur sehingga dalam analisisnya dilakukan secara subyektif dan akal-akalan.

2. Dari pihak nasabah (ekstern), dari pihak nasabah kemcaetan kredit dapat disebabkan akibat dua hal, yaitu:

a. Adanya unsur kesengajaan, dalam hal ini nasabah sengaja untuk tidak membayar hutangnya sehingga kredit yang diberikan macet. Dapat dikatakan tidak ada kemauan untuk membayar, walaupun sebenarnya mampu.

b. Adanya unsur tidak sengaja, artinya nasabah mau membayar tetapi tidak syarat-syarat administrasi yang harus dipenuhi oleh anggota untuk dapat memperoleh kredit, menurut Manager CU Bima Cabang Sintang adalah anggota biasa yang sudah mengikuti pendidikan dasar yang diselenggarakan oleh CU. Bima, dan sudah menjadi nasabah tabungan aktif minimal selama 2 bulan. Kemudian menurut Kepala Bagian Kredit CU Bima Cabang Sintang, seorang anggota dapat memperoleh pinjaman jika sudah mengikuti pendidikan dasar oleh koperasi dan aktif menabung selama 2 bulan. Pinjaman pertama paling tinggi 2 kali dari simpanan pokok, simpanan wajib dan simpanan suka rela anggota yang bersangkutan, atau paling tinggi sebesar Rp.35.000.000,- apabila layak dan ada barang jaminan. Sedangkan untuk pinjaman kedua dan seterusnya secara bertahap menyesuaikan dengan peningkatan jumlah simpanan yang bersangkutan dan prestasi atas pinjaman terdahulu.

Koperasi kredit atau credit union adalah usaha simpan pinjam, yang mengelola simpanan anggota dan kemudian menyalurkannya kembali dalam bentuk pinjaman kepada anggota juga, selisih jasa atau bunga dari pinjaman dan simpanan inilah yang menjadi laba atau keuntungan koperasi yang setelah dikurangi biaya-biaya inilah yang disebut sisa hasil usaha (SHU). Keuntungan koperasi dalam bentuk SHU ini akan dikembalikan kembali kepada para anggota dengan persentase yang sudah ditentukan sebelumnya. Dari hasil penelitian juga diketahui bahwa syarat administrasi yang dipersyaratkan untuk seseorang dapat meminjam sejumlah uang pada koperasi kredit sangatlah mudah, seseorang cukup menjadi anggota koperasi dengan menyimpan uang dalam bentuk simpanan wajib, simpanan pokok dan simpanan suka rela yang memang dipersyaratkan oleh koperasi. Setelah menjadi anggota, seseorang tersebut akan mendapat pendidikan dasar tentang koperasi kredit lebih mendalam. Setelah aktif menabung selama minimal 2 bulan, seseorang sudah dapat memperoleh fasilitas pinjaman atau kredit yang disediakan oleh koperasi kredit sesuai dengan kebutuhan yang diperlukannya.

Memproses pengajuan kredit pada CU Bima Kantor Cabang Sintang sudah dilaksanakan dengan baik, dan sesuai dengan prosedur yang ditetapkan oleh pengurus atau manajemen. Kemudian menurut Asisten Bidang Perkreditan CU Bima Kantor Pusat Kabupaten Sintang, bahwa dalam memproses pengajuan kredit pada CU Bima Kabupaten Sintang sudah diatur pengurus dan harus dipatuhi oleh seluruh cabang yang ada yang merupakan kantor operasional, yang melakukan kegiatan simpanan dan pinjaman. Kewenangan pimpinan cabang untuk memutuskan besar pinjaman yang dapat diberikan dibatasi hanya sampai sebesar Rp.10.000.000,-. Sedangkan pinjaman di atas Rp.10.000.000,- sampai Rp.35.000.000,- atau melebihi simpanan diputuskan oleh pimpinan cabang ditambah Asisten Bidang Kredit Kantor Pusat. Untuk pinjaman di atas Rp.35.000.000,- diputuskan oleh manajemen kantor pusat bersama pengurus. Segala peraturan mengenai pencairan kredit pada kantor cabang Sintang sudah ditetapkan dengan baik, dan selalu mengikuti peraturan yang telah ditentukan oleh pengurus yang tertuang dalam pola kebijaksanaan pengurus yang ditetapkan dalam Rapat Anggota Tahunan setiap tahunnya. Kepala Bagian Kredit menyatakan bahwa dalam menyalurkan kredit pada kantor cabang Sintang selalu mengikuti peraturan yang telah ditetapkan oleh pengurus, dimana kewenangan cabang dalam penyaluran kredit hanya sebesar Rp.10.000.000,dan jika di atas Rp.10.000.000,- sampai Rp.35.000.000,- pimpinan cabang memutuskan bersama Asisten Bidang Kredit, dan untuk pinjaman di atas Rp.35.000.000,- ke atas diputuskan oleh manajemen bersama pengurus CU Bima Kabupaten Sintang.

Dalam memberikan pinjaman atau kredit dikeluarkan beberapa produk pinjaman yang diusahakan dapat memenuhi kebutuhan akan dana dari anggota dan masyarakat sesuai dengan keperluannya, seperti pinjaman Umum, pinjaman Cumi, pinjaman Jangka Pendek, pinjaman Perumahan, dan pinjaman Perkebunan. Menurut Kepala Bagian Kredit, bahwa pinjaman yang disalurkan oleh CU. Bima cukup beragam, diantaranya pinjaman umum yang bertujuan untuk membantu anggota memenuhi kebutuhannya, untuk membantu usaha produktif anggota disediakan pinjaman Cumi dan pinjaman Jangka Pendek, untuk 
membantu anggota memiliki rumah sendiri dengan bentuk pinjaman Perumahan, sedangkan untuk membantu anggota mengolah lahan tidur dan usaha perkebunan disediakan pinjaman Perkebunan. Syarat-syarat yang harus dipenuhi oleh anggota agar dapat memperoleh fasilitas kredit atau pinjaman ditentukan atau dipersyaratkan sesuai dengan pinjaman yang diajukan, karena persyaratan administrasi yang ditentukan pada masing-masing pinjaman berbeda-beda. Untuk Pinjaman Umum ketentuan yang dipersyaratkan adalah jumlah pinjaman tertinggi Rp.35.000.000,- di atas simpanan saham, jangka waktu maximum 72 bulan, bunga pinjaman $2 \%$ menurun, jasa pelayanan $1 \%$ dari pinjaman yang dikabulkan, denda $3 \%$ dari jumlah tertunggak, sistem angsuran menurut atau tetap, toleransi waktu angsuran 10 hari dan atau tidak lewat dari bulan bersangkutan.

Pinjaman CUMI, dengan ketentuan sebagai berikut: Jumlah pinjaman tertinggi Rp.6.000.000,-, jangka waktu 30 hari, bunga pinjaman $0,20 \%$ tetap per hari, jasa pelayanan $2 \%$ dari pinjaman yang dikabulkan, denda $3 \%$ dari jumlah tertunggak dengan sistem angsuran tetap. Pada Pinjaman Jangka Pendek, dengan ketentuan sebagai berikut: jumlah pinjaman tertinggi Rp.200.000.000,-, jangka waktu maksimal 6 bulan, bunga pinjaman $3 \%$ menurun perbulan apabila pokok dan bunga diangsur setiap bulan, atau $3 \%$ tetap perbulan apabila dilunasi pada saat jatuh tempo, jasa pelayanan $1,5 \%$ dari pinjaman yang dikabulkan, denda $3 \%$ dari jumlah tertunggak, dan toleransi waktu angsuran 10 hari dan atau tidak lewat dari bulan yang bersangkutan. Pinjaman perumahan bertujuan membantu anggota untuk memiliki rumah sendiri, dengan ketentuan sebagai berikut: jumlah pinjaman tertinggi Rp.75.000.000,-, jumlah saham minimal $15 \%$ dari jumlah pinjaman, jangka waktu maksimal 10 tahun, bunga pinjaman $1,2 \%$ tetap, jasa pelayanan $1 \%$ dari pinjaman yang dikabulkan, denda $3 \%$ dari jumlah tertunggak. Pinjaman perkebunan membantu anggota mengolah lahan tidur dan atau peremajaan kembali, dengan ketentuan: jumlah pinjaman tertinggi Rp.15.000.000,-, wajib membuka Simpanan Perkebunan, jangka waktu 5 - 10 tahun, bunga pinjaman $1,1 \%$ tetap, jasa pelayanan $1 \%$ dari pinjaman yang dikabulkan, dan denda $3 \%$ dari jumlah tertunggak.

Syarat administrasi yang dipersyaratkan pada para anggota yang ingin meminjam uang pada koperasi kredit Bima Cabang Sintang tidaklah sulit, masyarakat yang ingin dapat meminjam cukup menjadi anggota koperasi dengan cara menyimpan uang dalam bentuk simpanan pokok, simpanan wajib dan simpanan sukarela. Dan setelah menjadi anggota akan diberikan pendidikan dasar yang menyangkut hal-hal yang berkaitan dengan apa dan bagaimana manfaat dari menjadi anggota koperasi, serta mengenai hak dan kewajiban sebagai anggota koperasi. Dari hasil pemantauan juga setiap anggota koperasi selalu diberikan bimbingan dan pengarahan agar dapat mengelola keuangan atau ekonomi keluarga, sehingga dengan menjadi anggota koperasi dapat mensejahterakan mereka sebagai anggota.

Sebelum menyalurkan kredit atau memberikan persetujuan kredit, bagian kredit perlu memberikan pertimbangan atau analisis kredit, yang menyangkut berbagai aspek serta seberapa besar anggota dapat diberikan kredit dan seberapa besar kemampuan anggota untuk mengembalikan pinjaman. Kemudian menurut Kepala Bagian Kredit diperoleh informasi bahwa sebelum kredit diberikan terlebih dahulu pihak koperasi dalam hal ini bagian kredit harus mengadakan analisis kredit. Analisis kredit ini mencakup latar belakang nasabah, prospek usahanya, jaminan yang diberikan, kemampuan mengembalikan pinjaman, atau catatan pinjaman sebelumnya.

Tujuan dilakukannya analisis kredit adalah agar pihak koperasi merasa yakin bahwa kredit yang diberikan benar-benar aman, karena pemberian kredit tanpa dianalisa terlebih dahulu akan membahayakan usaha koperasi kredit. Selanjutnya menurut Kepala Bagian Kredit, analisis kredit sebelum memutuskan untuk menyetujui pinjaman sangat diperlukan, tanpa analisis kredit suatu permohonan tidak akan dicairkan atau disetujui. Analisa kredit ini untuk menjaga agar pinjaman yang diberikan tidak macet, atau tertunda pembayarannya yang selanjutnya dapat mengakibatkan kerugian bagi usaha koperasi kredit. Dalam menganalisa kredit ada beberapa prinsip yang selalu menjadi pertimbangan oleh koperasi kredit Bima Kantor Cabang Sintang, dalam menganalisa kredit harus selalu memperhatikan prinsip-prinsip perkreditan yang dikenal dengan istilah five $\mathrm{Cs}$ of Credit atau $5 \mathrm{C}$, yaitu melakukan penilaian terhadap watak atau karakter calon nasabah, kemampuan debitur dalam mengembalikan pinjaman pokok dan bunga, untuk mengetahui modal debitur, jaminan yang diberikan dan nilainya, serta bagaimana kondisi perekonomian debitur. Kemudian menurut Kepala Bagian Kredit, bahwa selain prinsip $5 \mathrm{C}$ yang dilakukan dalam menganalisa kredit, dalam penyaluran kredit kepada anggota senantiasa memperhatikan permohonan pinjaman, yaitu apa tujuan peminjaman, bagaimana keteraturan dalam menabung, kemampuan mengembalikan, prestasi masa lalu, dan partisipasi anggota atau kepedulian anggota terhadap koperasi sebagai milik bersama.

Berdasarkan hasil pengamatan penulis, setiap permohonan kredit yang masuk selalu dibuatkan analisa kreditnya oleh petugas analisis 
kredit yang ditunjuk dan memiliki kompetensi untuk melakukan analisa kredit. Terkadang juga petugas sampai turun ke lapangan untuk melihat usaha pemohon, serta melihat jaminan yang diberikan oleh pemohon.

Dari hasil penelitian diperoleh informasi bahwa semua kredit yang disetujui di CU. Bima Cabang Sintang sudah dilakukan analisa kredit sebelumnya oleh tenaga bagian kredit yang berkompeten. Dari analisis kredit inilah seorang pemohon dapat diberikan kredit atau pinjaman sesuai dengan kemampuan yang dimiliki oleh calon debitur untuk dapat mengembalikan kredit. Bagi CU. Bima Cabang Sintang analisis kredit ini perlu dilakukan untuk memberikan keyakinan bahwa pinjaman yang diberikan benar-benar aman dan dapat membantu anggota meningkatkan taraf hidupnya. Dana yang diberikan kepada anggota adalah juga dana anggota koperasi yang harus dikelola dengan baik, untuk itulah pada CU. Bima Cabang Sintang tidak ada pinjaman yang disalurkan tanpa dianalisa terlebih dahulu, karena disadari tanpa analisa kredit yang cermat dan tepat dapat membahayakan usaha koperasi kredit. Dari hasil penelitian diketahui bahwa pada CU. Bima Cabang Sintang dalam menganalisa kredit selalu memperhatikan prinsip-prinsip standar dalam pemberian kredit yang dikenal dengan istilah Five Cs of Credit atau $5 \mathrm{C}$, yang menyangkut Character, Capacity, Capital, Collateral, dan Condition. Selain itu juga dalam penyaluran kredit kepada anggota senantiasa melihat permohonan kredit yang diajukan, mengenai maksud dan tujuan melakukan pinjaman, bagaimana keaktifannya dalam menabung, memprediksi kemampuan mengembalikan dengan melihat prestasi masa lalu, serta peran serta anggota atau kepeduliannya terhadap keberadaan koperasi sebagai usaha milik bersama.

Pengendalian kredit adalah kebijakan yang diambil oleh pengurus koperasi kredit dalam usaha menjaga aktiva lancar yang berbentuk tagihan yang timbul karena adanya pemberian pinjaman kepada para anggota dan senantiasa menjaga agar tidak terjadi tunggakan dalam pengembalian kredit yang diberikan. Menurut Kepala Bagian Kredit, pengendalian kredit adalah upaya pengurus koperasi kredit untuk menjaga likwiditas arus kas yang menyangkut pemberian dan pengembalian kredit dapat berjalan lancar. Tujuan pengendalian kredit adalah untuk mengetahui apakah kredit yang diberikan telah berjalan sesuai dengan rencana, untuk mengetahui apakah kredit yang telah diberikan dapat dikembalikan sesuai dengan perjanjian. Selanjutnya juga untuk mengetahui apakah kredit yang diberikan benar-benar digunakan sebagaimana mestinya, untuk mengetahui jumlah kelalaian atau resiko atas pinjaman yang tidak mampu dikembalikan oleh anggota yang telah diberikan pinjaman. Tujuan dilakukannya pengendalian kredit adalah untuk mengendalikan atau mengawasi bagaimana usaha-usaha yang dibiayai dari pinjaman sesuai dengan yang direncanakan. Dari pengendalian kredit ini juga untuk dapat mengetahui apakah ada kelemahan, kekurangan, pemborosan, kebocoran, kelalaian dan penyelewengan yang terjadi dan untuk selanjutnya dipikirkan bagaimana solusinya agar bisa keluar dari permasalahan yang dihadapi.

Dari hasil penelitian diketahui bahwa untuk menjaga agar aktiva lancar yang berupa tagihan atas pinjaman yang diberikan tetap lancar atau tidak macet, maka pihak CU. Bima Cabang Sintang sesuai dengan Pola Kebijaksanaan Pengurus selalu melakukan pengendalian kredit. Pengendalian kredit ini dilakukan untuk mengetahui apakah kredit yang diberikan telah berjalan sesuai dengan rencana atau digunakan sebagaimana mestinya, dan juga untuk mengetahui apakah kredit yang diberikan dapat dikembalikan sesuai dengan perjanjian yang telah disepakati bersama antara anggota dan pihak koperasi. Dari hasil penelitian diperoleh informasi bahwa proses pengendalian kredit pada CU. Bima Cabang Sintang telah dilakukan sebagaimana adanya dan terus menerus, sehingga dapat menekan angka kredit macet pada setiap tahunnya. Disadari oleh pengurus dan manajemen koperasi bahwa dana yang telah disalurkan alam bentuk pinjaman harus selalu diawasi, sehingga dapat diketahui sedini mungkin kelemahan, kelalaian atau penyelewengan dan segera dicarikan solusinya agar bisa keluar dari permasalahan yang dihadapi dan tidak terjadi kredit macet.

Kredit macet adalah resiko akibat pemberian pinjaman atau kredit yang tidak dapat dikembalikan oleh debitur oleh karena beberapa sebab baik yang disengaja maupun tidak disengaja. Sedangkan menurut Kepala Bagian Kredit CU. Bima Kantor Cabang Sintang kredit macet adalah pinjaman oleh anggota yang telah melampaui jangka waktu yang diperjanjikan dan tidak dapat ditagih kembali. Langkah-langkah yang diambil dalam menangani kredit macet adalah memperingatkan melalui surat kepada nasabah yang jika sampai dengan saat jatuh tempo pembayarannya belum juga membayar, menghubungi melalui telepon jika melalui surat juga belum dibayar oleh nasabah, jika belum juga dibayar maka dilakukan kunjungan rumah untuk menagih langsung, yang terakhir melakukan tindakan hukum dengan mengajukan gugatan perdata melalui pengadilan. Selanjutnya menurut Kepala Bagian Kredit diketahui bahwa tindakan terhadap nasabah yang menunggak pembayaran pinjaman dilakukan semata-mata untuk melakukan penyelamatan terhadap kemungkinan macetnya suatu kredit, langkah-langkah yang diambil dalam 
menangani nasabah atau debitur yang terlambat membayar pada koperasi kredit dilakukan dengan hati-hati dan sesuai dengan tahapan prosedural yng ditetapkan.

Prosedur administrasi dalam penyelesaian kredit macet sudah dapat dilaksanakan tepat pada waktunya sesuai dengan peraturan yang telah ditetapkan. Selanjutnya menurut Kepala Bagian Kredit CU. Bima Cabang Sintang bahwa tahapan proses administrasi selalu diikuti dalam menyelesaikan kredit macet yang terjadi, dan dalam pelaksanaannya sudah dapat dilaksanakan sesuai dengan waktu yang ditetapkan. Dari hasil penelitian diketahui bahwa, resiko yang ditimbulkan dari pemberian pinjaman dengan jangka waktu tertentu adalah resiko tidak dikembalikannya pinjaman atau macet, baik yang disengaja maupun tidak disengaja oleh debitur. Untuk menangani kredit macet pada CU. Bima Cabang Sintang telah dilakukan langkahlangkah antisipatif sesuai dengan prosedur, yaitu dengan membuat surat teguran kepada nasabah atau debitur yang pembayarannya sudah jatuh tempo namun belum membayar. Kemudian jika belum juga membayar akan dilakukan langkah menelpon langsung ke debitur yang bersangkutan, selanjutnya melakukan penagihan langsung ke rumah, dan yang terakhir jika belum juga dibayar akan dilakukan tuntutan secara perdata melalui pengadilan. Dari hasil penelitian ini diketahui bahwa prosedur administrasi yang dilakukan CU. Bima Cabang Sintang dalam penyelesaian kredit macet, selalu dilakukan semata-mata untuk melakukan penyelamatan terhadap kemungkinan macetnya suatu kredit. Sebelum melakukan tindakan administratif, biasanya petugas bagian kredit akan terlebih dahulu melakukan pendekatan personal untuk mengetahui permasalahan yang mengakibatkan seorang debitur terlambat atau menunggak membayar angsuran pinjaman. Pada kesempatan ini petugas akan memberikan bimbingan dan bantuan pemecahan masalah yang yang dihadapi oleh debitur yang bermasalah tersebut, sehingga debitur dapat kembali membayar angsuaran pokok dan bunga pinjaman secara rutin dan teratur.

\section{KESIMPULAN DAN SARAN}

\section{Kesimpulan.}

Dari hasil penelitian dan pembahasan yang dilakukan pada bab-bab terdahulu, maka penelitian ini dapat disimpulkan sebagai berikut: Prosedur dalam menyalurkan kredit kepada para anggota pada CU Bima Sintang adalah pemenuhan syarat administrasi, setelah syarat administrasi dipenuhi, anggota dapat mengajukan permohonan kredit dan kemudian pihak koperasi kredit melakukan analisa kredit terhadap permohonan pinjaman yang masuk, barulah kemudian suatu permohonan kredit dapat disetujui atau ditolak. Dalam memenuhi kebutuhan masyarakat atau anggota pihak manajemen koperasi kredit memberikan beberapa jenis fasilitas kredit yang sesuai dengan kebutuhan anggotanya. Kemudian teknik dalam menyelesaikan masalah kredit macet dilakukan dengan pengendalian kredit yang bertujuan untuk menjaga agar aktiva lancar dalam bentuk tagihan akibat penyaluran kredit tidak tejadi tunggakan dalam pengembaliannya. Disamping itu juga dilakukan tindakan administratif pada nasabah pinjaman yang menunggak pembayaran kreditnya, sesuai dengan prosedur yang telah ditetapkan oleh Pengurus CU. Bima Kabupaten Sintang yang tertuang dalam Pola Kebijaksanaan Pengurus. Faktor-faktor yang mempengaruhi kredit macet pada CU. Bima Cabang Sintang disebabkan oleh faktor intern dan faktor ekstern. Faktor intern adalah faktor yang disebabkan dari dalam koperasi itu sendiri, sedangkan faktor ekstern adalah faktor yang disebabkan oleh nasabah pinjaman yang tidak mengembalikan pinjaman dikarenakan sebab yang disengaja maupun yang tidak disengaja. Kredit macet yang terjadi pada CU. Bima Cabang Sintang lebih banyak diakibatkan oleh faktor dari luar, yaitu lebih disebabkan oleh kemampuan nasabah pinjaman yang tidak ada lagi untuk membayar pinjaman yang diberikan. Untuk mengatasi masalah tersebut oleh pihak CU. Bima telah dilakukan langkah-langkah yang tepat sesuai dengan peraturan yang telah ditetapkan oleh pihak pengurus, yaitu melalui penjadwalan kembali hutang maupun dengan melakukan penghapusbukuan terhadap pinjaman yang macet.

\section{Saran-Saran.}

Dari kesimpulan di atas, penulis menyarankan beberapa hal sebagai berikut :

Diharapkan kepada pihak manajemen CU. Bima Cabang Sintang, dapat diberikan kewenangan yang lebih besar dalam menyetujui kredit, agar kebutuhan anggota akan dana yang lebih besar dapat dipenuhi cukup pada kantor cabang saja, tanpa harus sampai kepada kantor pusat. Diharapkan kepada Pengurus atau Manajer untuk segera menindak lanjuti dengan cara menagih kepada nasabah yang mulai lalai membayar kreditnya, sebelum kredit tersebut menjadi macet.

Diharapkan kepada pihak koperasi untuk terus memotivasi agar terus meningkatkan simpanan, dan terus menyarankan agar koperasi kredit menjadi satu-satunya tempat menyimpan dan mengelola transaksi keuangan keluarga, baik untuk menyimpan maupun meminjam guna memenuhi kebutuhannya. 
Evy Ratnasari, Upaya Manager Pada Credit Union Dalam Menanggulangi Kredit Macet 186

\section{DAFTAR PUSTAKA}

Adi, R. 2004. Metodologi Penelitian Sosial dan Hukum. Jakarta: Granit.

Ali, F. 1997. Metodologi Penelitian Sosial Dalam Bidang Ilmu Administrasi dan Pemerintahan. Jakarta: PT. Rajagrafindo Persada.

Arikunto, S. 2000. Prosedur Penelitian Suatu Pendekatan Praktis. Jakarta: Rineka Cipta.

Baswir, R. 2000. Koperasi Indonesia. Yogyakarta: BPFE.

Elias, A dan Bernadus, S.L.S. 2006. Manajemen Perkreditan untuk Credit Union (Koperasi Kredit) dan Koperasi Simpan Pinjam (KSP). Jakarta: Publikasi Inkopdit.
Faisal, S. 2005. Subjek-Subjek Penelitian. Jakarta: PT. Rajagrafindo Persada.

Fabozzi, P.J. dkk. 1994. Foundations of Financial Markets and Institutions (Terjemahan). Pasar dan Lembaga Keuangan. Jakarta: Salemba Empat.

Hendrojogi, 2000. Koperasi : Asas-Asas, Teori dan Praktek. Jakarta: PT. Rajagrafindo Persada.

Husnan, S. 1998. Manajemen Keuangan Teori dan Penerapan. Yogyakarta: BPFE.

Kasmir. 2003. Dasar-Dasar Perbankan. Jakarta: PT. Rajagrafindo Persada.

Keputusan Pengurus Kopdit Bima Nomor 001 Tahun 2008. Tentang Pola Kebijaksanaan Pengurus Tahun Buku $=2008$. 